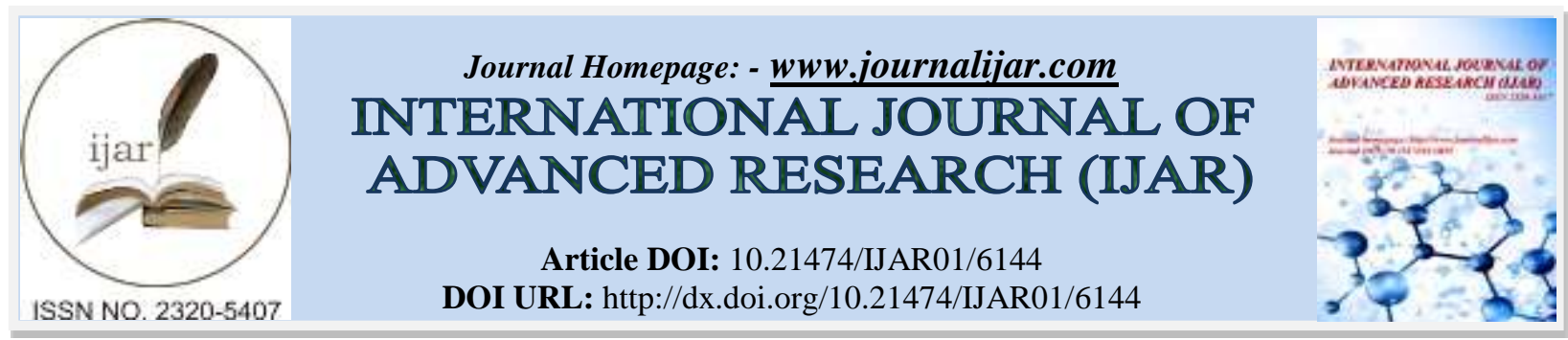

RESEARCH ARTICLE

\title{
PLANT HORMONES SYNTHESIZED BY MICROORGANISMS AND THEIR ROLE IN BIOFERTILIZER-A REVIEW ARTICLE.
}

\begin{abstract}
Shweta Sharma ${ }^{1}$ and Mohinder Kaur ${ }^{2}$.
1. Department of plant pathology, Dr Yashwant Singh Parmar University of Horticulture and Forestry, Nauni, Solan-173230.

2. Department of Basic Science (Microbiology), Dr Yashwant Singh Parmar University of Horticulture and Forestry, Nauni, Solan-173230.
\end{abstract}

\section{Manuscript Info}

Manuscript History

Received: 23 October 2017

Final Accepted: 25 November 2017

Published: December 2017

Key words:-

Plant growth promoting rhizobacteria, phytohormones, IAA, gibberellins, cytokinins, abscisic acid and ethylene

\section{Abstract}

Plant growth promoting rhizobacteria (PGPR) are the soil bacteria inhabiting around/on the root surface and are directly or indirectly involved in promoting plant growth and development via production and secretion of various regulatory chemicals in the vicinity of rhizosphere Various species of bacteria like Pseudomonas, Azospirillum, Azotobacter, Klebsiella, Enterobacter, Alcaligenes, Arthrobacter, Burkholderia, Bacillus and Serratia have been reported to enhance the plant growth directly by either assisting in resource acquisition (nitrogen, phosphorus and essential minerals) or modulating plant hormone levels, or indirectly by decreasing the inhibitory effects of various pathogens in the forms of biocontrol agents. The ability to synthesize growth stimulating phytohormones by numerous prokaryotic and eukaryotic microorganisms including numerous soil bacteria and fungi is reviewed, with emphasis on their effect on plant physiology and development. A phytohormone is an organic substance synthesized in defined organs of the plant that can be translocated to other sites, where it triggers specific biochemical, physiological and morphological responses. The commonly recognized classes of phytohormones, regarded as the "classical five", are: the auxins, gibberellins, cytokinins, abscisic acid and ethylene. Several PGPR are reported to produce IAA, gibberellic acid and cytokinins in the rhizospheric soil and thereby play a significant role in increasing the root surface area and number of root tips in many plants. Plant hormones contribute to the coordination of diverse physiological process in plants, including the regulation of quiescence and seed germination, root formation, fluorescence, branching, tillering, and fruit ripening. They increase plant resistance to environmental factors and induce or suppress the expression of genes and the synthesis of enzymes, pigments and metabolites (Arsad and Frankenberger, 1991; Kulaeva and Kuznetsov, 2002).

Copy Right, IJAR, 2017,. All rights reserved. 


\section{Discovery of plant hormones:-}

Auxins: The discovery of auxins during the nineteenth century was outcome of experiments on phototropism and geotropism (reviewed by Moore, 1979). In 1880 Charles Darwin reported on the phenomenon by which the plants bent towards the sunlight. In 1926, the Dutch botanist Frits W. Went discovered auxin and described its bioassay for its quantitative detection by "Avena coleoptile curvature test". Although Went had succeeded in isolating auxin, he was not able to purify the active compound to establish its chemical structure. In 1934, the biochemist Kogl HaageSmit and Erxleben obtained an active substance from urine, indole-3-active acid (IAA), which was found to be identical to auxin. Finally K. V. Thimann isolated IAA from cultures of the fungus Rhizopus suinus in 1935.

\section{Gibberellins:-}

Gibberellins was discovered by E. Kurosawa in 1926(Moore, 1979). In Japan disease called foolish seedling or bakanne in maize and rice seedling treated with spent-culture medium from fungus Gibberella fujikuroi was reported. Yabuta and Sumiki, in 1938 isolated and crystallized two biologically active substances, which they named as gibberellins "A and B". In 1956, gibberellins were shown to be natural compound of the plant tissues both by West and Phinney in USA and by Radley in England. Up to now about 125 different GAs (Gibberellins) have been characterized (Crozier et al., 2001).

\section{Cytokinins:-}

The discovery of the cytokinins occurred in 1955, when Skoog isolated a substance called kinetin from an autoclaved sample of DNA, and demonstrated it to be active in vitro in promoting mitosis and cell division in tobacco callus tissue. Although kinetin is an artifact derived from 2-deoxyadenylate, its biological activity resembles that of zeatin (Z), a native inducer of plant cell division that was isolated from immature maize seedling 1963.

\section{Ethylene:-}

Ethylene is also known as "ripening hormone" was identified some 50 years ago (Burg, 1962). Many soil bacteria code for enzyme aminocyclopropane deaminase (ACC-deaminase) that degrades a key intermediate in ethylene accumulation by plants (Penrose and Glick, 2003).

\section{Abscissic acid:-}

Abscissic acid was discovered around 1960 as the hormone causing abscission of fruits and dormancy of buds.

\section{Production and role of phytohormones:-}

There are two sources of phytohormones naturally available for the plants: endogenous production by the plant tissues and exogenous production by the associated microorganisms (Kumar and Lonsane, 1989; Arshad and Frankenberger, 1991; Costacurta and Vanderleyden 1995; Patten and Glick 1996). Many plant associated microorganisms are themselves capable of synthesizing phytohormones (given in table 1) which are necessary as mediator in communications between the plant host and its microflora. The ability to form plant hormones is believed to be a major property of rhizospheric, epiphytic and symbiotic bacteria that stimulate and facilitate plant growth called as plant growth promoting rhizobacteria (PGPR) strains (Kameneva and Muronets, 1999; Karvchenko et al., 2004; Suzuki and Oyaizu, 2003). On the other hand, certain free-living microorganisms (i.e. those that form no association with plants in the course of the life cycle) are also capable of synthesizing plant hormones.

Table.1:- Phytohormones produced by plants and microorganisms and their effect on plant morphology and development

\section{Auxin Production}

\begin{tabular}{|c|c|c|c|}
\hline S.no. & $\begin{array}{l}\text { Plant endogenous production or } \\
\text { Causative agent }\end{array}$ & Observed effect on plant & Reference \\
\hline \multirow[t]{2}{*}{1.} & Plant & & \\
\hline & $\begin{array}{l}\text { Zea mays } \\
\text { Arabidopsis thaliana }\end{array}$ & $\begin{array}{l}\text { Cell enlargement, root initiation, } \\
\text { vascular differentiation and apical } \\
\text { dominance }\end{array}$ & $\begin{array}{l}\text { Ostin } \text { et al., } 1999 \\
\text { Bartling } \text { et al., } 1994\end{array}$ \\
\hline \multirow[t]{2}{*}{2.} & Fungus & & \\
\hline & Pisolithus thaliana & Plant growth promotion & $\begin{array}{l}\text { Frankenberger } \\
\text { Poth, } 1987\end{array}$ \\
\hline \multirow[t]{2}{*}{3.} & Bacteria & & \\
\hline & Azospirillum & Decrease of root length, increase & Tien et al., 1979 \\
\hline
\end{tabular}




\begin{tabular}{|c|c|c|}
\hline $\begin{array}{l}\text { Rhizobium } \\
\text { Bradyrhizobium }\end{array}$ & of root hair development & $\begin{array}{l}\text { Atzorn et al.,1982 } \\
\text { Badenosch-Jones et al., } \\
1982\end{array}$ \\
\hline Klebsiella & $\begin{array}{l}\text { Increase in root branching and } \\
\text { root surface }\end{array}$ & $\begin{array}{ll}\text { El-Kawas } & \text { and } \\
\text { Adachi,1999 } & \\
\end{array}$ \\
\hline $\begin{array}{l}\text { Azospirillum, Gluconobacter, } \\
\text { Herbaspirillum }\end{array}$ & $\begin{array}{l}\text { Corn seedling inoculated showed } \\
\text { an increase on free active IAA } \\
\text { and IBA }\end{array}$ & $\begin{array}{l}\text { Fuentes-Ramirez } \\
\text { al., } 1993 \\
\text { Bastian } \text { et al., } 1998 \\
\text { Fallik et al.,1989 }\end{array}$ \\
\hline $\begin{array}{l}\text { Pseudomonas syringae pv savastanoi } \\
\text { Agrobacterium } \\
\text { Erwinia herbicola pv gypsophilae }\end{array}$ & $\begin{array}{l}\text { Induction of gall and tumor } \\
\text { formation }\end{array}$ & $\begin{array}{l}\text { Comai and Kosugue, } \\
1980 \\
\text { Liu et al., } 1982 \\
\text { Manulis et al., } 1998\end{array}$ \\
\hline Cyanobacteria Nostoc & Symbiotic tissue of Gunnera & Sergeeva et al.,2002 \\
\hline
\end{tabular}

Gibberellins production

\begin{tabular}{|c|c|c|c|}
\hline S.no. & $\begin{array}{l}\text { Plant endogenous production or } \\
\text { Causative agent }\end{array}$ & Obsereved effect on plant & Reference \\
\hline \multirow[t]{2}{*}{1.} & Plant & & \\
\hline & $\begin{array}{l}\text { Arabidopsis Thaliana } \\
\text { Oryza sativa } \\
\text { Zea mays } \\
\text { Pisum satvium }\end{array}$ & $\begin{array}{l}\text { Seed germination development } \\
\text { and reproduction of plants, floral } \\
\text { development }\end{array}$ & $\begin{array}{l}\text { Kobaysahi et al., } 1994 \\
\text { Helliwell et al.,2001 } \\
\text { Spray et al., } 1996\end{array}$ \\
\hline \multirow[t]{2}{*}{2.} & Fungus & & \\
\hline & Gibberellia fujikuroi & $\begin{array}{l}\text { Bakanae effect in maize, rice and } \\
\text { other plants }\end{array}$ & $\begin{array}{l}\text { Rojas et al.,2001 } \\
\text { Fernadez-Martin et al., } \\
1995\end{array}$ \\
\hline \multirow[t]{3}{*}{3.} & Bacteria & & \\
\hline & $\begin{array}{l}\text { Azospirllum brasilense } \\
\text { Azospirllum lipoferum }\end{array}$ & $\begin{array}{l}\text { Reversion of dwarfism in maize } \\
\text { and rice }\end{array}$ & Cassan et al.,2001 \\
\hline & Azospirllum brasilense & $\begin{array}{l}\text { Promotion of shoot elongation, } \\
\text { growth and root hair density }\end{array}$ & Fulchieri et al.,1993 \\
\hline
\end{tabular}

Cytokinins production

\begin{tabular}{|l|l|l|l|}
\hline S.no. & $\begin{array}{l}\text { Plant endogenous production or } \\
\text { Causative agent }\end{array}$ & Observed effect on plant & Reference \\
\hline 1. & Plant & $\begin{array}{l}\text { Cell division phloroplast } \\
\text { differentiation, photosynthesis, } \\
\text { senescence al.,2001 } \\
\text { metabolism }\end{array}$ & nutrient \\
\hline $\mathbf{2 .}$ & Arabidopsis thaliana & Plant growth promotion & Roberto and Kosuge,1995 \\
\hline & Bacteria & $\begin{array}{l}\text { Induction of gall and tumor } \\
\text { Formation }\end{array}$ & Lichter et al.,1995 \\
\hline
\end{tabular}

\section{Auxins:-}

Auxin represents one of the most important plant hormones regulating many aspect of plant growth and development throughout the plant cell cycle from cell division,cell elongation and differentiation to root initiation, apical dominance, tropistic response, flowering, fruit ripening and senescence (stress to stress factors ) 
IAA (indole acetic acid) exhibits the greatest activity although plants are known to contain other auxins, most of them also belonging to indole derivatives (structurally similar to IAA). This indole may be precursors or products of the transformation of IAA. The ability to synthesis IAA was detected in many rhizospheric and epiphytic bacteria: Azospirillum spp., Agrobacterium spp., Azotobacter spp. Alcaligenes spp., Entrobacter spp. Erwinia spp., Acetobacter spp., Rhizobium spp., Bradyrhizobium spp., and Herbasirillum spp. (Cacciari et al., 1989; Datta and Basu, 2000). The formation of IAA is widespread among bacteria of the genera Pseudomonas, Bacillus and Xanthomonas spp. (Wilkinson et al.,1994; Olyunina and Shabaev,1996; Tsavkelova et al, 2005; Park et al.,2005;Mordukhova et al.,1991) as well as Methylobacteria (Methylobacterium, Methylovorus, Aminobacter and Paracoccus) (Ivanova,2001) Biosynthesis of auxins was noted in Achromobacter, Flavobacterium, Arthrobacter, Klebisella, Rhodococcus, Mycobacterium, Sphingomonas, Stenotrophomonas, Micrococuccus (Belimov et al.,1999). Many Streptomycetes and certain respresentatives of Archaea (e.g. thermophylic sp. Sulfolobus acidocaldaris) also synthesise IAA(White,1987) The capacity of IAA biosynthesis was found in representatives of free living and symbiotic cyanobacteria of the genera Nostoc, Chlorogloeopsis, Calothrix, Plectonema, Gloeothece, Anabeana, Cylindrospermum and Anabaenopsis.

Among phototropic eukaryotes IAA formation was noted in algae of the genera Chlorella, Dunaliella and Fucus (Basu et al., 2002) Yeast of the genus Saccharomyces and Micromycetes belonging to the genera Fusarium, Rhizoctonia, Rhizopus, Absidia, Aspergillus, Pencillium, Monilia, Phoma, Pythium, Trichoderma and Actinomucor also produce IAA(Gunasekaran and Weber, 1972). Mycorrhizal fungi of the genera Laccaria, Pisolithus, Amanita, Rhizopogon, Paxillus and Hebeloma. In plant cells IAA is largely formed by de novo synthesis from tryptophan, which undergoes either oxidative deamination (via formation of indole-3-pyruvic acid) or decarboxlation (via formation of tryptamine, with indole-3-acetic aldehyde as an intermediate). In case of microorganisms, the known pathways of IAA biosynthesis are also related to tryptophan metabolism.

1. IAA formation via indole -3-pyruvic acid and indole-3-acetic aldehyde is found in majority of microorganism, such as the phytopathogenic bacterium Erwinia herbicola, saprophytic species of the genera Agrobacterium and Pseudomonas, certain representatives of Bradyrhizobium, Azospirillum, Rhizobium Klebsiella and Enterobacter; Methylobacteria ; the symbiotic nitrogen fixing cyanobacterium Nostoc sp. ; the yeast Saccharomyces uvarum and phytopathgenic micromycetes of the genera Fusarium, Rhizoctonia and Colletotrichum (Furukawa,1996; Thakur, and Vyas, 1983)

2. The conversion of tryptophan into indole-3-acetic acid aldehyde may involve an alternative pathway in which tryptamine is formed. This pathway is believed to operate in pseudomonades and azospirilla, anundentified mycorrhizal fungus of orchid (Ophrys lutea Cav.) (Barroso, 1986) and the cyanobacterium Chlorogloea fritschii (Ahmad, and Winter, 1969).

3. IAA biosynthesis via indole-3-acetamide formation takes place in phytopathogenic bacteria Agrobacterium tumefaciens, Pseudomonas syringe and E. herbicola; certain streptomycetes; saprophytic pseudomonades Pseudomonas putida and Pseudomonas fluorescence.

4. IAA biosynthesis that involves tryptophan conversion into indole-3-acetonitrile is found in plant, Alcaligenes fecalis and possibly, the cynobacterium Synechocystis sp.

5. The tryptophan-independent pathway, more common in plants, is also found in microorganisms (Azospirillium and Cynobacteria)

However, the contribution of this pathway to IAA biosynthesis is insignificant and the mechanisms are largely unknown. In plant, IAA binds to sugars, amino acids and protein, forming storage (inactive) forms which release the phytohormone when it is needed (the physiological activity is recovered shortly thereafter). Omission of tryptophan from the culture medium decreases the level of IAA synthesis by the culture's microorganisms. Exogenous tryptophan may augment auxin biosynthesis by an order of magnitude or higher, this being the reason why the yield of the phytohormone in the most active strains exceeds $80-100 \mathrm{mg}$ IAA per $1 \mathrm{ml}$ culture medium (Tsavkelova et al.,2003).

\section{Gibberellins:-}

A substance including excessive extension of rice sprouts, first isolated from the phytopathogenic fungus Fusarium moniliforme in the 1930s, was given the name gibberellins (after the perfect stages of Fusarium monilifomra, Gibberella fujikoroi) (Escamilla et al.,1999). Gibberellins, classified with diterpenes, consist of isoprene residues that usually form four rings (A, B, C and D). Gibberellic acids (GAs), $\mathrm{GA}_{3}, \mathrm{GA}_{7}, \mathrm{GA}_{1}$, and $\mathrm{GA}_{4}$ are the best studied phytohormones of this group; they exhibit maximum biological activity and are the most widespread in nature. Gibberellins amount to more than 100 compounds, constituting the largest class of phytohormones, which are found 
in both plants and microorganisms. Certain compounds are classified with gibberellins based solely on their characteristic biological activity (they have a different structure). First and foremost, gibberellins affect the division and elongation of the cells constituting the intercalary meristem, although stimulation of fluorescence, activation of the synthesis of membranes and amylolytic enzymes, and other effects have also been described. The ability to synthesize gibberellins is inherent in all groups of microorganisms (Badenoch-Jones et al., 1982). Gibberellins are formed by epiphytic and rhizospheric bacteria (representatives of the genera Azotobacter, Arthrobacter, Azospirillum, Pseudomonas, Bacillus, Acinetobacter, Flavobacterium, Micrococcus, Agrobacterium, Clostridium Rhizobium and Xanthomonas) (Grappelli and Rossi, 1981; Cassan et al., 2001).

The Gibberellins (GAs) are complex molecules of tetracarbocyclic diterpernes. GAs numbering is not related to their structure. Molecules, whose structure has been elucidated, are numbered in approximate order of their discovery. There is continuing interest in the biosynthic origin of the GAs since some of them have important activities in plants. The most important $\mathrm{GA}$ in plant is $\mathrm{GA}_{1}$, primarily responsible for stem elongation. In Gibberellia, GAs biosynthesis is catalyzed by enzymes falling into three classes: terpene cyclases catalyze the synthesis of ent-kaurene from geranylgernayl diophosphate; cytochrome P450 monooxygenase catalyze the steps of the pathway from ent-kaurene to $\mathrm{GA}_{12}$; and soluble dioxynenase catalyze the final steps of the pathway.

The ability of Azospirillum lipoferum and Azospirillum brasilense to metabolize $\mathrm{GA}_{20} \mathrm{GA}_{1}$ in rice (Oryza sativa L.) seedlings suggests that an enzyme similar to that operating in plants (2-oxyglutarate-dependent dioxygenase) is involved in gibberellins biosynthesis in these bacteria (belonging to the genera Azotobacter, Pseudomonas and Lactobacillus) certain yeast strains, and mycelia rhizospheric fungi.GA increases the growth rate and promotes nitrogen fixation in cyanobacteria of the genus Anabaena and it also stimulates the formation of lytic enzymes in certain bacteria and fungi (Vinklarkova and Sladky,1978; Barea,1974 ).

\section{Cytokinins:-}

Cytokinins are adenine derivatives. The first compound exhibiting cytokinin activity was isolated from the semen of herring. Subsequently, a factor responsible for control of cell division was isolated from maize (Zea mays L.); hence named as zeatin. The second natural cytokinin to be identical was isopentenyadenine; this compound was a minor base in serine tRNA of yeast. Studies with slime mold Dictyostelium discoideum revealed that 5'-AMP was a direct precursor of isopentenyl adenosine 5'-phosphate. The enzyme catalyzing this conversion, dimethylallyl diphosphate: 5'-AMP transferase (or isopentenyl transferase) was also found in cell-free extract from maize kernels, and from tobacco callus tissue cultures that became cytokinin-autonomous. Recently several genes encoding the isopentenyl transferase have been identified from Arabidopsis thaliana. A corresponding enzyme from the bacterium Agrobacterium tumefaciens, encoded by the ipt gene, has been studied in depth at the molecular level, and the same gene was also found in Pseudomonas syringae pv. savastanoi, where it is named ptz.

Depending on the chemical structure of their molecules (i.e. on the nature and position of a substituent in the purine ring), cytokinins exhibit diverse physiological activities. The multiplicity of functions performed by cytokinins allows them to regulate a wide range of physiological responses: activation of cellular RNA and protein synthesis, stimulation of plant cell division, promotion of the branching (tillering), interruption of the quiescence of dormant buds, activation of seed germination, regulation of chloroplast formation, stabilization of photosynthetic apparatus under the conditions of water stress and augmentation of general resistance of the cells to a variety of adverse environmental factors(Chernyad'ev,2005). Cytokinins are capable of potentiating the activities of RNA polymerase and matrix chromatin, and thereby affect protein synthesis. Microorganisms are capable of synthesizing kinetin, zeatin, isopentenyladenine and some other cytokinin derivatives.

Cytokinins are formed by rhizobacteria (belonging to the genera Rhizobium, Azotobacter ,Azospirillum, Arthrobacter, Bacillus and Pseudomonas) and certain streptomycetes (Upadhyaya et al.,1991). The ability to synthesize cytokinins is inherent in methylotropic and methanotropic bacteria (belonging to the genera Methylobacterium, Methylomonas, Methylopila, Methyloarcula, Methylophylus, Methylobacillus,Methylovorus, Xanthobacter, Paracoccus, Blastobacter, Hyphomicrobium and Methylosinus)( Shepelyakovskaya et al.,1999). PGPR strains (i.e. Pseudomonas fluorescence and phytopathogenic bacteria Agrobacterium tumefaciens, Erwinia herbicola, Pseudomonas solanacearum, P. syringae and Rhodococcus fascians) from cytokinins, in addition to auxins.

The synthesis of cytokinins is tRNA -dependent in Pseudomonas aeruginosa, Rhizobium spp., Rhodococcus fascians, and the fungus Taphrina cerasi (Gray, 1996). In the majority of cases, however, tRNA degradation 
produces inactive cis-isomers of zeatin, whereas the active trans-isomers are formed by de novo biosynthesis. On the other hand, tRNA of the diazotropic bacterium Azotobacter vinelandii was found to contain 2-methylthioribosyltrans-zeatin.

\section{Ethylene:-}

Ethylene biosynthesis by plants originates from methionine. The first step is the synthesis of S-adenosyl-methionine, followed by its conversion into 1-aminocyclopropane-1-carboxylic acid (ACC). ACC is the direct precursor of ethylene. The ACC oxidase, formerly known as the ethylene-forming enzyme (EFE), was first characterized in apple. Ethylene production has been also reported for bacteria and fungi.

Phytohormone-like substances formed by microorganisms affect not only the plant host, but also the producer microorganisms, which undergoes the necessity of holistic approaches to the plant and its associated micro biota as components of a single system. Some researchers believe that excretion of IAA by bacteria grown under unfavorable condition may have considerable functional importance as a factor increasing the probability of forming plantmicroorganism association. This conclusion based on the finding that the amount of IAA reaches maximum values during the steady-state stage of development, characterized by nutrient depletion. The role of hormones as regulatory substances should therefore be viewed on abrader scale, because they act as intermediaries not only in processes confined to plant tissues, but also in communications of diverse organisms inhabiting the same ecological niche. Each participant of such a community has an intrinsic biochemical activity and pursues its own ends; both pathogenic and symbiotic microorganisms, however, excrete the same phytohormones. The difference in the resulting effect is not infrequently reduced to the concentration of a phytohormone. In this particular this case, microorganisms populating the root surface and capable of excreting phytohormones gets advantages in its colonization (Maor et al., 2004).

\section{Role of microbial phytohormones in plant growth promotion as biofertilizers:-}

Plant growth regulators are widely used as stimulants of seed and tuber germination, accelerators of root formation and fruit ripening, agents for controlling plant growth and development, and means of increasing crop productivity. Growth stimulators accelerate and augment root formation (in plants where root age poses problems or does not occur under normal conditions) and regulate quiescence. phytohormones are used against viral infections and diseases caused by phytophogenic fungi. The use of phytohormones is indispensive in all cases where a whole plant is grown from an in vitro plant tissue culture.

1. PGP Effect on Crops of Agronomic Importance:- The observed PGP (plant growth promotion) effect include modifications of the root morphology after inoculation with Azospirillum, such as a dramatic increase of length and density of roots hairs, increase in root branching and root surface area, which led to an enhanced uptake of water and minerals. All these effects have been tentatively attributed to the production phytohormones such as IAA, gibberellins and kinetin by the bacteria (Jain and Patriquin, 1984).

2. Use of low IAA producers:- The effect of Azosirillum inoculation on the plant is concentration dependent leading to the promotion or inhibition of root growth (Dobbelaere et al., 1999). Thus inoculation with Azospirillum mimics typical growth response induced by auxins, which are inhibitory of plant growth at high concentrations and stimulatory at lower levels.

3. Use of plant hormone producer microorganisms as inoculum for many crops:- Microbial phytohormones exert beneficial effects when plant seeds, seedlings etc. are treated with cultures and /or suspensions of producer microorganisms. Seeds treatment with soil rhizobacteria Azospirillum, Bejerinckia, Rhizobium, Agrobacterium, Bacillus, Pseudomonas, Mycobacterim, Arthrobacter, Methylovorus, and Flavobacterium strongly stimulates the germination capacity and germination in seed, also increasing the growth and crop productivity in mature plants(Dileep,1998). The augmentation of the growth rate correlates with the increase in ability of the bacteria to colonize the plant and the amount of the phytohormones formed (Zvyagintsev, 1995). Strains of rhizobacteria producing small amounts of auxins increased considerably the development of wheat (Triticum aestivum L.) and its crop productivity. Inoculation with cytokinin-producing methylobacteria of transgenic tobacco plants characterized by altered morphology (rootlessness) restored root formation and the effects of the microorganism culture on seed germination and plant development were similar to those of the phytohormones or the culture liquid of methylobacteria. Treatment of dwarf rice (which lacks the ability to synthesize gibberellins) with Azospirillum lipoferum and A. brasilense resulted in a pronounced stimulation of plant growth. This effect was due to the ability of the bacteria to metabolize exogenous GA20 (gibberellins 20) into the biologically active GA1 (Tudzynski, 1999). Moreover, , industrial production of gibberellins for agriculture relies primarily on the cultivation (on an industrial scale) of the fungus Fusarium moniliforme, the perfect stage of which (Gibberella 
fujikoroi) produces considerable amounts of diverse gibberellins. (Polyanskaya et al., 2002). Bacterial treatment of seed makes it possible to achieve germination of germination-resistant seed of rare, decorative or industrially important plants. Thus, bacteria of the genera Pseudomonas, Bacillus, Xanthomonas, Rhodococcus and Micrococcus, which all form auxins, strongly stimulate symbiotic germination of the seeds of tropical orchids and accelerate their development under greenhouse conditions. It should be taken into account that the beneficial effects of bacterial treatment depend on a variety of factors, including the activity of the strain, the concentration of the cells, the amount of phytohormones in the culture liquid, the quantity of the dry preparation of the stimulating microorganism, the duration of the treatment, the species of the plant the state of the indigenous microflora at the time of seeding, the characteristics of the soil and the general conditions of the agro technological complex. The introduction of bacterial inoculums is more successful if the strains are isolated from the rhizoplane or rhizosphere of mature plants of the same species (Lalande et al., 1989). It is not frequent that stimulation of plant growth and development by PGPR (plant growth promoting rhizobacteria) strains of bacteria is underlain not only by phytohormone formation, but also by their capacity for nitrogen fixation, improvement of plant nutrition (water and mineral) and prevention or suppression of phytopathogen growth; the latter effect is due to excretion by PGPR strains of bactericidal and fungicidal substances (Glick and Pasternak, 1998).

4. Sugar cane promotion:- Up to $80 \%$ of the total $\mathrm{N}$ incorporated into several sugar cane cultivars can be attributed to BNF (biological nitrogen fixation). In addition, the growth promotion can be driven by a hormonedependent mechanism. Under N-sufficient growth condition, plants inoculated with Gluconacetobacter diazotrophicus, either as the wild type or a nifD mutant are approximately $20 \%$ taller than non inoculated plants. These results suggested that Gluconacetobacter diazotrophicus could benefit sugarcane by two ways: by transfer of bacterial nitrogen fixed and as well as via phytohormones production (Sevilla et al, 2001).

5. Gain in root length associated to ACC-deaminase:- Ethylene plays an inhibitory role on root elongation. A role for the ACC-deaminase in preventing ethylene effect was shown in inoculation experiments of canola roots by E.cloacae. The plant growth promotion effect is linked to the lowering of plant ethylene levels by the bacterial ACC-deaminase.

\section{Conclusion:-}

Understanding of IAA, Gibberellins and cytokinins metabolism calls for further identification and analysis of the intermediates, enzyme and genes involved in their biosynthesis, as well as in the isolation of mutants defective in each pathway. Although the production of phytohormones at the free living state is well established in many microorganisms, there is still insufficient evidence for their synthesis in their natural habitats. The ecological significance of phytohormones production by bacteria would be more convincing if it could be demonstrated that bacterial phytohormones production occurs while bacteria colonize the root system. As both the plant and the bacteria synthesize and secrete auxins, gibberellins and cytokinins is difficult to address the contribution of one particular hormone as responsible of the effects observed. Thus the possibility that the host plant directs the bacterium to produce IAA through Trp present in root exudates is intriguing and speculative at this point.

Plant-associated microflora is the richest source of microorganisms synthesizing phytohormones. The bulk of evidence shows that phytohormones formed by fungi, algae and bacteria are structurally identical to their plant counterparts. In future, the use of transcriptional (or other type) fusion for the analysis of the differential expression of the bacterial genes involved in phytohormones biosynthetic pathways in association with the host plant should generate important information.

In recent years, a number of studies on inoculation of cereal crops (wheat, maize, sugar cane, sorghum and sunflower) and horticulture crops with PGPR have been performed. Beneficial effects such as increases in nitrogen content and yield have been reported in Belgium, Israel, France, Argentina, Uruguay, Mexico, USA and South Africa. Success of field experiments depends of many parameters, such as the strain used, concentration of bacterial inoculum, viability of bacteria during storage, carrier employed, appropriate inoculation methodology, and soil characteristics. The identification of many traits and genes related to the beneficial effects of inoculated bacteria shall result in a better understanding of the performance of bioinoculants in the field. It will also provide a strategy to design genetically modified strains with improved PGP effects. This multiplicity of effects of phytohormones determines the function of the plant-microorganism community as a whole. The productive efficiency of a specific PGPR may be further enhanced with the optimization and acclimatization according to the prevailing soil conditions. In future, they are expected to replace the chemical fertilizers, pesticides and artificial growth regulators which have numerous side-effects to sustainable agriculture. Further research and understanding of mechanisms of 
PGPR mediated-phytostimulation would pave the way to find out more competent rhizobacterial strains which may work under diverse agro-ecological conditions.

\section{References:-}

1. Arshad, M., Frankenberger J.W.T. (1991).Microbial production of plant hormone. The rhizosphere and plant growth. In: Keister, D.L., Cregan, P.B.,editors. The Netherland: Kluwer Academic. PubI; 327-334.

2. Kulaeva, O.N., Kuznetsov, V.V. (2002). Fiziol Rastenii 49 (4),626-640.

3. Moore, T.C. (1979).Biochemistry and physiology of plant hormones. Spring-Verlag:New Yark

4. Crozier, A., Kamiya,Y., Bishop, G., Yakota, T.(2001).Biosynthesis of hormones and elicitors molecules. In:Buchanan, B.B.,Grussem, W., Jones, R.L. editors.Biochemistry and molecular biology of plants. American society of plants biologists; 850-900.

5. Burg, S P.(1962). The physiology of ethylene formation. Annual Review of Plant Physiology13, 265-302.

6. Penrose, D.M., Glick, B.R.(2003).Methods for isolating and characterizing ACC deaminase containing plant growth-promoting rhizobacteria. Physiology plant 118, 10-15.

7. Kumar, P. K.R., Losane, B.K.(1989). Microbial production of gibberellins: state of the art. Advances Application of Microbiology 134, 29-139.

8. Costacurta, A., Vanderleyden, J.(1995).Synthesis of phytohormones by plant-associated bacteria. Critical Review of Microbiology 21, 1-18.

9. Patten, C. L., Glick, B.R.(2000a).Bacterial biosynthesis of indole-3-acetic acid. Canadian Journal of Microbiology 42, 207-220.

10. Kameneva, S. V., Muronets, E. M.(1999).Genetika 35(11), 1480-1494.

11. Kravchenko, L.V., Azarova, T. S., Makarova, N. M., Tikhonovich, I. A.(2004).Mikrobiologiya. 73(2), 195198.

12. Suzuki, S. He. Y.,Oyaizu, H.(2003).Current Microbiololy 47(2), 138-143.

13. Osten, A.N., Cohen, J.D.(1999). An in vitro system from maize seedlings for tryptophan - independent inodole-3acetic acid biosynthesis. Plant Physiology 119,173-178.

14. Frankenberger, Jr. W. T., Poth, M.(1987). Biosynthesis of indole-3-acetic acid by pine ectomycorrhizal fungus Pisolithus tinctorius. Application of Environment Microbiology 53,2908-2913.

15. Bartling, D., Seedrof, M., Schmidt, R.C., Weiler, E. M.(1994).Molecular characterization of two cloned nitrilases from Arabidopsis thaliana key enzyme in biosynthesis of plant hormone indole-3-acetic acid.Proc.Nati.Acad.Sci.USA.91,6021-6025.

16. Tein, T. M., Gaskins, M. H., Hubbell, D. H.(1979). Plant growth substances produced by Azospirillum brasilense and their effect on the growth of Pearl Millet (Pennisetum americanum L.) Applied Environment Microbiology 37, 1016-1024.

17. Atzorn, R., Crozier, A., Wheeler, C. T., Sandberg, G. (1988).Production of gibberellins and indole-3-acetic acid by Rhizobium phaseoli in relation to nodulation of Phaseoli vulgaris roots. Planta.175, 532-538.

18. Badenoch-Jones, J., Summons, R. E., Djordjevic, M. A., Shine, J., Letham, D. S., Rolfe, B. G.(1982).Mass spectrometric quantification of indole-3-acetic acid in culture upernatants of Rhizobium strains, studies in relation to root hair curling and Applied Environment Microbiology 44, 275-280.

19. El-Khawas, H., Adachi, K.(1999).Identification and quantification of auxins in culture media of Azospirillum and Klebsiella and their effect on rice roots. Biology of Fertile Soils 28, 377-381.

20. Fuentes-Ramirez, L. E., Jimenez, Salgado, T., Abarca, Ocampo, I. R., Caballero-Mellado,J.(1993). Acetobacter diazotrophicus an indoleacetic acid producing bacterium isolated from sugarcane cultivars of Mexico. Plant Soil154, 145-150.

21. Bastian, F., Cohen, A., Piccoli, P., Luna, V., Baraldi, R., Bottini, R.(1998). Production of indole-3-acetic acid and gibberellinsA1 and A3 by Acetobacter diazotrophicus and Herbaspirillum seropedicae in chemicallydefined culture media. Plant Growth Regulators24, 7-11.

22. Fallik, E., Okon, Y., Epstein, Y. E., Goldman, A., Fischer, M.(1989). Identification and quantification of IAA and ABA in Azospirillum brasilense inoculated maize roots. Soils Biology and Biochemistry21,147-153. Comai, L., Kosuge, T.(1980). Involvement of plasmid deoxyribonucleic acid in indoleacetic acid synthesis in Pseudomonas savastanoi. Journal of Bacteriology143,959- 957.

23. Liu, S. T., Perry, K. L., Schardl, C. L., Kado, C. I.(1982). Agrobacterium Ti plasmid indoleacetic acid gene is required for crown gall oncogenesis. Proc. Natl. Acad. Sci. USA 79, 2812-2816. 
24. Maulis, S., Haviv-Chesner, A., Brandl, M. T., Lindow, S. E., Barash, I.(1998). Differential involvement of indole-3-acetic acid biosynthesis a pathway in pathogenicity and epiphytic fitness of Erwinia herbicola pv. gysophilae. Mol. Plant-Microbe Interiact11,634-642.

25. Sergeeva, E., Liaimer, A., Bergaman, B.(2002). Evidence for the production of the phytohormone indole-3acetic acid by cyanobacteria.Planta171, 1718-1724.

26. Kobayashi, M., Gaskin, P., Spray, C., Phinney, B. Mac Millan, J.(1994). The metabolism of A1 by tall and dwarf mutants of Oryza sativa and Arabidopsis thaliana.Plant Physiology106, 1367-1372.

27. Helliwell, C. A., Chandler, P. M., Poole, A., Dennis, E. S., Peacock, W. J.(2001). The CYP88A cytochrome P450, ent-kaurenoic acid oxidase, catalyzes three steps of the gibberellins biosynthesis pathway. Proc.Natl.Acad.Sci.USA98, 2056-2070.

28. Spray, C. R., Kobayashi, M., Suzuki, Y., Phinney, B. O., Gaskin, P., MacMillan, J.(1996). The $d$ warf- $l(d l)$ mutant of Zea mays blocks three steps in the gibberellins biosynthesis pathyway. Proc. Natl. Acad. Sci. U.S.A 93, 10515-10518.

29. Rojas, M.C., Hedden, P., Gaskin, P., Tudzynski, B.(2001). The P450-I gene of Gibberella fujikuroi encodes a multifunctional enzyme in gibberellin biosynthesis. Proc. Natl. Acad. Sci. USA 98, 5838-5843.

30. Fernandez-Martin, R., Reys, F., Domenech, C. E., Cabrera, E., Bramley, P. M., Barrero, A. F., Avalos, J., Cerda- Olmedo, E.(1995).Gibberellin biosynthesis in gib mutants of Gibberella fujikuroi. Journal of Biology and Chemistry270,14970-14974.

31. Cassan, F., Bottini, R., Schneider, G., Piccoli, P.(2001). Azospirillum brasilense and Azospirillum lipoferum hydrolyze conjugates of $\mathrm{GA}_{20}$ and metabolize resultant aglycones to $\mathrm{GA}_{1}$ in seedlings of rice dwarf mutants. Plant Physiology 125, 2053-2058.

32. Fulchieri, M., Lucangeli, C., Bottini, R.(1993). Inoculation with Azospirillum lipoferum affects growth and gibberellins status of corn seedling roots. Plant Cell Physiology 34, 1305-1309.

33. Takei, K., Sakakibara, H., Sugiyama, T.(2001). Identification of genes encoding adenylate isopentenyltransferase, a cytokinin biosynthesis enzyme in Arabidopsis thaliana. Journal of Biology and Chemistry 276, 26405-26410.

34. Roberto, F., Kosuge, T.(1987). Phytohormone metabolism in Pseudomonas syringae subsp. Savastanoi. In: Fox, J. E., Jacob, M. editors. Molecular biology of plant growth control 371-380.

35. Lichter, A., Barash, I., Valinsky, L., Manulis, S.(1995).The genes involved in cytokinin biosynthesis in Erwinia herbicola pv. gypsophilae, characterization and role in gall formation. Journal of Bacteriology177, 4457-4465.

36. Cacciari, I., Lippi, D., Pietrosanti, T., Pietrosanti, W.(1989). Plant Soil 115, 151-153.

37. Datta, C., Basu, P.(2000). Microbiology Reviews 155(2), 123-127.

38. Wilkinson, K., Dixon, K., Sivasithamparam, K., Ghisalberti, E.(1994).Plant Soil154,291-295.

39. Olyunina, L.N., Shabaev, V. P.(1996).Mikrobiologiya 65(6), 813-817.

40. Tsavkelova, E. A., Cherdyntseva, T. A., Netrusov, A. I.(2005). Mikrobiologiya.74(1), 55-62.

41. Park, M., Kim, C., Yang, J., Lee, H., Shin, W., Kim, S., Sa, T.(2005). Microbiology Reviews160(2), 127 133.

42. Mordukhova, E. A., Skvortsova, N. P., Kochetkov, V. V.,Dubeikovskii A N and Boronin A M.(1991). Mikrobiologiya 60 (3), 494-500.

43. Ivanova, E. G., Doronina, N. V., Trotsenko, Yu, A.(2001).Mikrobiologiya70(4),452- 458.

44. Belimov, A. A., Ivanchikov, A., Yu., Yudkin, L.V., Khamova, O. F., Postavkaya, S. M., Popolzukhina, P. V., Shamakova, A. A., Kozlova, G. Yu.(1999). Mikrobiologiya68(3),392-397.

45. White, R.(1987). Journal of Bacteriology 169(12),5859-5860.

46. Basu, S., Sun, H., Brian, L., Quatrano, R., Muday, G.(2002). Plant Physiology130(1), 292-302.

47. Gunasekaran, M., Weber, D. (1972). Mycologia.64,1180-1183.

48. Furukawa, T., Koga, J., Takashi, A., Kishi, K., Syono, K.(1996). Plant Cell Physiology37,899-905.

49. Barroso, J., Chaves, Neves, H., Pais, M.(1986). New Phytology 103, 745-749.

50. Ahmad, M., Winter, A. (1969). Planta.88,61-66.

51. Tsavkelova, E. A., Cherdyntseva, T. A., Netrusov, A. I.(2003). Mikol. Fitopatol37(5), 5-83.

52. Escamilla, S. E. M., Dendooven, L., Uscanga, R. J. A., Monroy, R. A. I., Gonzalez, A. G. de la, Torre, M. M.(1999). World Journal of Microbiol. Biothechnology 15,753-755.

53. Badenoch-Jones, J, Summons, R., Djordjevic, M., Shine, M., Letham, D., Rolfe, B.(1982). Applied Environment Microbiology44(2), 275-280.

54. Grappelli, A., Rossi, W.(1981). Folia Microbiology (Praha).26(2),137-141.

55. Cassan, F., Lucangeli, C., Bottini, R., Piccoli, P. (2001). Plant Cell Physiology 42 (7),763-767. 
56. Vinklarkova, K., Sladky, Z. (1978). Folia Microbiology (Praha).23(1), $55 \square 59$.

57. Barea, J., Navarro, E., Palomares, A., Montoya, E.(1974).Journal of Applied Bacteriology37,171-174.

58. Chernyad'ev, I.I. (2005). Prikl. Biokhimiya I Mikrobiologiya41(2),133-147.

59. Upadhyaya, N., Letham, D., Parker, C., Hocart, C.,Dart, P. (1991). Biochem. Int. 24(1),123-130.

60. Shepelyakovskaya, A.O., Doronina, N.V., Laman, A.G., Brovko, F.A.,Trotsenko,Yu.A.(1999). Dokl. Akad. Nauk 368(4),555-557.

61. Gray, J., Gelvin, S., Meilan, R., and Morris, R. (1996). Plant Physiology 110(2), 431-438.

62. Maor, R., Haskin, S., Levi-Kedmi, H., Sharon, A. (2004). Applied Environmental Microbiology70 (3),18521854.

63. Jain, P., Patriquin, D. (1984). Root deformation bacterial attachment and plant growth in wheat-Azospirillum association.Applied Environmental Microbiology 48, 1208-1213.

64. Dobbelare, S., Croonenborghs, A., Thys, A., Vande Broek, A., Vanderleyden, J. (1999). Phytostimulatory effect of Azospirillum brasilense wild type strain and mutant strains altered in IAA production on wheat. Plant Soil 212, 155-164.

65. Dileep, C., Kumar, B., Dileep, S., Dube, H.C.( 1998). Indian Journal of Experimental Biololgy36 (4), $399-$ 402.

66. Zvyagintsev, D.G. (1995). Impacts Appl. Microbiol. Biotechnol. Thes. 10th Int. Conf.Glob, Ellsinghore: IAMS.

67. Tudzynski, B. (2005). Applied Microbiol Biotechnology66,597-611.

68. Polyanskaya, L.M., Vedina, O.T., Lysak, L.V., Zvyagintsev, D.G. (2002). $\quad$ Mikrobiologiya71(1), 123129.

69. Lalande, R., Bissonnette, N., Coutlée, D., and Antoun, H. (1989). Plant Soil 115, 7-11.

70. Glick, B.R., Pasternak, J.J.( 2002). Molecular Biotechnology. Principles and Applications of Recombinant DNA. Molekulyarnaya biotekhnologiya. Printsipyi primenenie. Washington, DC: ASM Press.

71. Sevilla, M., Burris, R. H., Gunapala, N. and Kennedy, C. (2001). Comparison of benefit to sugarcane plant growth and ${ }^{15} \mathrm{~N}_{2}$ incorporation following inoculation of sterile plants with Acetobacter diazotrophicus wild type and Nif mutants strains. Molecular Plant- Microbe Interaction14, 833-843. 